\title{
FLAVONOIDS AND COUMARINS FROM HIERACIUM PILOSELLA L. (ASTERACEAE)
}

\author{
MONIKA GAWROŃSKA-GRZYWACZ1 ${ }^{1}$, TADEUSZ KRZACZEK ${ }^{2}$ \\ ${ }^{1}$ Department of Toxicology of Medical University of Lublin \\ 2 Department of Pharmaceutical Botany of Medical University of Lublin \\ Chodźki 8, 20-093 Lublin, Poland \\ e-mail:migg1@wp.pl
}

(Received: January 12, 2009. Accepted: June 25, 2009)

\begin{abstract}
Typical chromatographic methods were successfully applied to isolate nine flavonoid compounds and two coumarin glycosides from the inflorescences and the herb of Hieracium pilosella L. Repeated column chromatography, occasionally paper chromatography and recrystallization made the separation of three flavonoid aglycones and six glycosides - possible. Coumarin glycosides were isolated by preparative thin layer chromatography. Subsequent UV, NMR and MS analyses have led to identification of the following flavonoid derivatives: known for the species - apigenin, luteolin, luteolin 7-O- $\beta$-glucopyranoside, luteolin 4'-O- $\beta$-glucopyranoside, isoetin 7-O- $\beta$ -glucopyranoside, isoetin 4'-O- $\beta$-glucuronide and new for the species - kaempferol 3-methyl ether and apigenin 7-O- $\beta$-glucopyranoside. Third isoetin glycoside contained two different sugar moieties: xylose and glucose, probably attached to the hydroxyl groups at C-4' or C-4' and C-2'(or 5') of an aglycone. Umbelliferone 7-O- $\beta$-glucopyranoside (skimmin) and new for the genus Hieracium esculetin 7-O- $\beta$-glucopyranoside (cichoriin) were determined by NMR and MS methods.
\end{abstract}

KEY WORDS: Hieracium pilosella, flavonoids, coumarin glycosides, LC, NMR, LSI MS.

\section{INTRODUCTION}

Hieracium pilosella L. (mouse-ear hawkweed) is a common plant and a very invasive weed, native to Eurasia, but it has been also introduced into North America and into New Zealand. In Poland mouse-ear hawkweed grows widely on dry meadows and sunny slopes of hills (Broda and Mowszowicz 2000).

In our previous work phenolic acids and also steroids like phytosterols and triterpenoids were identified and determined in this species (Gawrońska-Grzywacz and Krzaczek 2006a, b; 2007; Krzaczek et al. 2002). So far some articles have reported the presence of coumarins or flavonoids in mouse-ear hawkweed, but none of them has concerned possibly the most complete isolation and full spectral identification of these polyphenolic biologically active components (Bate-Smith et al. 1968; Haag-Berrurier and Duquénois 1962, 1963; Harborne 1978; Henn et al. 1988; Sheluyto et al. 1977; Zidorn et al. 2002, 2005). Especially interesting three derivatives of isoetin (hieracin) - a rare $5,7,2^{\prime}, 4^{\prime}, 5^{\prime}$-pentahydroxyflavone and its undescribed diglycoside among them, were obtained from the methanolic extract of $H$. pilosella. Recently the cytotoxity of isoetin derivative has been reported (Rahman et al. 2007). Untill now eleven different glycosides of isoetin have been identified in some species from the family Asteraceae mostly, also in representatives of the genus Hieracium (GluchoffFiasson et al. 1991; Harborne 1978, 1991; Marco et al. 1988; Pauli and Junior 1995; Shi et al. 2008; Zidorn et al. 2002, 2005).

Herba Pilosellae is well-known in European ethno-medicine and traditionally used to treat inflammations of the urinary tract and also skin diseases because of its diuretic, astringent, antiseptic and antiphlogistic activity (Agelet and Vallès 2003; Beaux et al. 1999; Bolle et al. 1993; Wright et al. 2007). The knowledge of benzo- $\alpha$-pirone (e.g. coumarins) and benzo- $\gamma$-pirone (flavonoids) derivatives present in this species is still incomplete and undoubtedly many therapeutic values of this plant may be attributed to these constituents.

The aim of the presented study was isolation and identification of flavonoids and coumarins from the herb and inflorescences of the investigated plant. The easy-approachable methods of liquid chromatography have been applied to reach the separation purpose. The structure elucidation was based on the results of the spectroscopic experiments (UV, 1D and 2D NMR, LSI MS). 


\section{MATERIAL AND METHODS}

\section{Plant material}

The plant material for research were herb and inflorescences of Hieracium pilosella L. collected in Ćmiłów near Lublin in 2002 and 2004. It was dried in normal conditions and adequately fragmented according to Polish Pharmacopoeia VI. $800 \mathrm{~g}$ of herb (without inflorescences) and 1000 $\mathrm{g}$ of inflorescences were used in the study. The voucher specimen was deposited at the Herbarium of the Department of Pharmaceutical Botany, Faculty of Pharmacy, Medical University of Lublin.

\section{Extraction and isolation}

The air-dried plant materials were exhaustively extracted with boiling $80 \%$ methanol. The raw extract obtained from the herb was evaporated under vacuum and the residue was eluted with hot distilled water and after 24 hours partitioned with chloroform. Next the aqueous phase was partitioned with ethyl acetate and this organic layer was used to isolate flavonoid and coumarin glycosides. The extract obtained from inflorescences was used for the separation of the flavonoid aglycones and glycosides.

The methods of preparative column, paper and thin layer chromatography were optimized during the process of isolation. Preliminary column chromatography on polyamide using methanol - water gradient solvent system (0-100\% or $70-100 \%, \mathrm{v} / \mathrm{v})$ and ethyl acetate - methanol - water $(18: 5: 2 \mathrm{v} / \mathrm{v})$ provided fractions for further investigations. Repeated preparative column chromatography was done on polyamide and Sephadex LH-20 and toluene - methanol ( $5: 3$ and $8: 3, v / v)$ on polyamide and methanol on Sephadex LH-20 were the best mobile phases for the separation of three flavonoid aglycones (compounds 1-3). In turn, 55\% and $60 \%$ aqueous solutions of methanol on Sephadex LH20 revealed the most effective for isolation of two flavonoid glycosides (compounds 5 and 6). Preparative paper chromatography was performed on Whatman $3 \mathrm{CHR}$ sheets, $460 \times 460 \mathrm{~mm}$, using ascending technique development. Among seven different mobile phases tested, 20\% aqueous acetic acid and TBA (t-buthanol - acetic acid - water, $3: 1: 1 \mathrm{v} / \mathrm{v}$ ) were chosen to separate the constituents of two various flavonoid fractions, yielding three glycosides (compounds 4, 7 from herb and 9). However in two cases of purification following two flavonoid glycosides multiple crystallization was very helpful (compounds 7 from inflorescences and 8). Coumarin glycosides (compounds 10 and 11) were isolated by preparative thin-layer chromatography on silica gel plates developed in distilled water.

\section{Acid hydrolysis}

All glycosides (compounds 4-11) were hydrolyzed with 2 $\mathrm{mol} / \mathrm{l} \mathrm{HCl}$ at $100^{\circ} \mathrm{C}$ for $1 \mathrm{~h}$. After cooling, the mixtures were filtered if a precipitate appeared and next extracted with ethyl ether. The organic and aqueous fractions were analyzed by TLC and NMR spectroscopy and the structures of respectively aglycones and sugar moieties were elucidated by comparison with authentic standards or literature data.

\section{Structure elucidation}

All obtained flavonoid compounds were analyzed by RPHPLC (Knauer Liquid Chromatograph equipped with K-2001 UV detector) to verify their purity. The analyses were performed using Hypersil columns $(200 \times 5 \mathrm{~mm}$, particle size $5 \mu \mathrm{m})$ and acetonitrile - water solvent system (5$-60 \%$ or $18-60 \%, \mathrm{v} / \mathrm{v}$ ) in gradient elution and $20 \%$ or $45 \%$ aqueous solutions of acetonitrile in isocratic elution. The flow rate of mobile phase was $1 \mathrm{ml} / \mathrm{min}$ and chromatograms were recorded at $254 \mathrm{~nm}$ and $360 \mathrm{~nm}$.

The structures of the isolated compounds were elucidated on the basis of: 1D- and 2D-NMR spectroscopy $\left({ }^{1} \mathrm{H}\right.$ NMR, ${ }^{13} \mathrm{C} \mathrm{NMR},{ }^{1} \mathrm{H}-{ }^{1} \mathrm{H} \mathrm{COSY}$, and in some cases also ${ }^{1} \mathrm{H}-{ }^{13} \mathrm{C}$ HMQC, ${ }^{1} \mathrm{H}-{ }^{13} \mathrm{C}$ HMBC; spectrometer Bruker Avance DRX500; 500,13 MHz for ${ }^{1} \mathrm{H}$ NMR and 125,75 $\mathrm{MHz}$ for ${ }^{13} \mathrm{C} \mathrm{NMR}$; in DMSO- $d_{6}$ or $\left.\mathrm{CD}_{3} \mathrm{OD}\right)$, liquid secondary-ion mass spectrometry (LSI MS, Cs+, $13 \mathrm{keV}$, in glycerine, spectrometer Finnigan MAT 95, Finnigan MAT $\mathrm{GmbH}$, Bremen, Germany) and UV spectrophotometry (spectrophotometer Hitachi U-2001) by comparing the obtained data with those in literature. Melting points (Boetius, Franz Küstner Nachf. KG, Dresden HMK, Germany) where also compared and co-chromatography (1D-, 2D-TLC) with authentic standards (LGC Promochem, ChromaDex, Inc. USA; Roth GmbH, Germany) were done wherever possible. One-dimensional thin layer chromatography of the coumarin aglycones obtained after acid hydrolysis was performed on silica gel $60 \mathrm{~F}_{254}$ plates (Merck, Darmstadt, Germany) using following mobile phases: benzene ethyl acetate $(17: 3 \mathrm{v} / \mathrm{v})$, dichloromethane - ethyl acetate $(95: 5 \mathrm{v} / \mathrm{v})$ and chloroform - methanol $(8: 2 \mathrm{v} / \mathrm{v})$. In 2D-TLC (silica gel $60 \mathrm{~F}_{254}$ plates) analysis the chromatograms were developed in the first direction using benzene - chloroform - acetonitrile $(4,75: 4,75: 0,5 \mathrm{v} / \mathrm{v} / \mathrm{v})$, next in the second direction in benzene - ethyl acetate $(17: 3 \mathrm{v} / \mathrm{v})$ and again in the first direction in benzene - chloroform - ethyl acetate $(4,75: 4,75: 0,5 \mathrm{v} / \mathrm{v})$. The chromatograms were dried after every step. They were observed in ultraviolet light at $365 \mathrm{~nm}$ before and after spraying the plates with $10 \%$ ethanolic solution of potassium hydroxide. The coumarins were identified by comparing the fluorescence and the location of the spots of analyzed compounds with those of authentic standards. The best ability to separate flavonoid aglycones, isolated from plant material and also released after acid hydrolysis of glycosides, was shown by the following mobile phases: $50 \%$ aqueous solution of acetic acid and acetic acid - hydrochloric acid - water (30:3:10 v/v/v) on cellulose plates, whereas ethyl acetate - methanol - water $(20: 3: 2$ $\mathrm{v} / \mathrm{v} / \mathrm{v})$ and benzene - methanol $(5: 3 \mathrm{v} / \mathrm{v})$ on polyamide 11 $\mathrm{F}_{254}$ plates (Merck, Darmstadt, Germany). During the process of identification of two isolated flavonoid glycosides (compounds 7 and 9) the chromatograms were developed in n-buthanol - acetic acid - water (4:1:5 v/v/v) and/or TBA (1D-TLC and 2D-TLC as first direction, cellulose plates), $15 \%$ aqueous solution of acetic acid (1D and 2D-TLC as second direction, cellulose plates) and also in ethyl acetate - methanol - water $(18: 5: 3 \mathrm{v} / \mathrm{v} / \mathrm{v})$ on polyamide $11 \mathrm{~F}_{254}$ plates (1D-TLC only). The chromatograms were observed in ultraviolet light at $365 \mathrm{~nm}$ before and after exposure to ammonia vapours. Next, visualization was performed by spraying the plates with special reagents: $5 \%$ ethanolic solution of aluminium chloride or $2 \%$ ethanolic solution of Natural Product Reagent A (Roth $\mathrm{GmbH}$, Germany). The chromatograms after derivatization were dried and also observed in UV $(365 \mathrm{~nm})$. The flavonoids were identified on the basis of comparison with authentic standards. 
The sugars liberated after acid hydrolysis were analyzed by $1 \mathrm{D}$-TLC performed on cellulose plates using pyridine ethyl acetate - acetic acid - water (5:5:1:3 v/v/v/v) as mobile phase and also on silica gel $60 \mathrm{~F}_{254}$ plates using n-propanol - ethyl acetate - water $(7: 2: 1 \mathrm{v} / \mathrm{v} / \mathrm{v})$. Aniline phthalate spray reagent revealed the identity of the sugar(s) compared with co-chromatographed standards.

\section{RESULTS AND DISCUSSION}

From the inflorescences of Hieracium pilosella three flavonoid aglycones were isolated and identified as: luteolin (compound 1), apigenin (2) and kaempferol 3-methyl ether (3). Two glycosides of luteolin: 7-O- $\beta$-glucopyranoside (7) and 4'-O- $\beta$-glucopyranoside (8) were also obtained. The extract of this plant material provided additionally three isoetin derivatives: 7-O- $\beta$-glucopyranoside (5), 4'-O- $\beta$-glucuronide (6) and xyloside-glucoside (4). At the same time two coumarin glycosides were separated from the herb and identified as esculetin 7-O- $\beta$-glucopyranoside (10) and umbelliferone 7-O- $\beta$-glucopyranoside (11). This material also yielded luteolin 7-O- $\beta$-glucopyranoside (7) and apigenin 7-O- $\beta$-glucopyranoside (9).

Compound 1 appeared as yellow needles with melting point at $325-326^{\circ} \mathrm{C}$ (lit. $\mathrm{mp} 325-328^{\circ} \mathrm{C}$ (Haag-Berrurier and Duquénois 1969)). UV data with characteristic batochromic and hypsochromic shifts (see below) clearly showed the presence of hydroxyl groups at C-5, C-7 and C-4' and also ortho-dihydroxyl groups in the B-ring in a flavone nucleus. All the obtained values of the UV and ${ }^{1} \mathrm{H}$ NMR spectra (see below) were in a perfect agreement with literature data for luteolin (Haag-Berrurier and Duquénois 1969, Harborne 1999, Mabry et al. 1970). The identification was supported by 1D and 2D-TLC comparisons with authentic standard which revealed the same $\mathrm{R}_{\mathrm{f}}$ and fluorescence.

UV $\lambda{ }_{\text {MeOH }} \mathrm{nm}: 254,349$; (+ NaOMe): 266, 400; (+ $\left.\mathrm{AlCl}_{3}\right): 273,422 ;\left(+\mathrm{AlCl}_{3}+\mathrm{HCl}\right): 275,357,388 ;$ (+ $\mathrm{NaOAc}): 267,399 ;\left(+\mathrm{NaOAc}+\mathrm{H}_{3} \mathrm{BO}_{3}\right): 252,267,373$;

${ }^{1} \mathrm{H}$ NMR (DMSO- $\left.d_{6}\right): \delta 6,17(1 \mathrm{H}, d, J=2,0 \mathrm{~Hz}, \mathrm{H}-6)$, $6,43(1 \mathrm{H}, d, J=2,0 \mathrm{~Hz}, \mathrm{H}-8), 6,67(1 \mathrm{H}, s, \mathrm{H}-3), 6,87(1 \mathrm{H}$, $d, J=8,2 \mathrm{~Hz}, \mathrm{H}-5$ ') 7,38 (1H, $\left.d, J=2,2 \mathrm{~Hz}, \mathrm{H}-2^{\prime}\right), 7,41$ $(1 \mathrm{H}, d d, J=2,1 ; 8,3 \mathrm{~Hz}, \mathrm{H}-6$ '), 12,98 (1H, s, 5-OH).

Compound 2 was a cream-yellow powder with $\mathrm{mp}$ at $340^{\circ} \mathrm{C}$ (lit. mp 335-338 ${ }^{\circ} \mathrm{C}$ (Klimek and Królikowska 1984)) and identical $R_{f}$ values and fluorescence like authentic apigenin. The UV spectral data were typical for flavone with free $\mathrm{OH}$ groups at C-5, C-7, C-4' and no orthodihydroxyl groups in the B-ring. Its UV and ${ }^{1} \mathrm{H}$ NMR data were in agreement with literature (Harborne 1999; Klimek and Królikowska 1984; Mabry et al. 1970).

UV $\lambda_{\max } \mathrm{MeOH}_{\mathrm{nm}}$ : 268, 335; (+ NaOMe): 275, 325, 392; $\left(+\mathrm{AlCl}_{3}\right): 276,302,347,384 ;\left(+\mathrm{AlCl}_{3}+\mathrm{HCl}\right): 277,300$, 340, 381; (+ NaOAc): 274, 345; (+ NaOAc $\left.+\mathrm{H}_{3} \mathrm{BO}_{3}\right): 268$, 338 ;

${ }^{1} \mathrm{H}$ NMR (DMSO- $\left.d_{6}\right): \delta 6,17(1 \mathrm{H}, d, J=1,8 \mathrm{~Hz}, \mathrm{H}-6)$, $6,46(1 \mathrm{H}, d, J=1,8 \mathrm{~Hz}, \mathrm{H}-8), 6,78(1 \mathrm{H}, s, \mathrm{H}-3), 6,91(2 \mathrm{H}$, $d, J=8,7 \mathrm{~Hz}, \mathrm{H}-3$ ', $\mathrm{H}-5$ ') $, 7,92$ (2H, $d, J=8,7 \mathrm{~Hz}, \mathrm{H}-2$ ', H$\left.-6^{\prime}\right), 12,96(1 \mathrm{H}, s, 5-\mathrm{OH})$.

Compound 3 with $\mathrm{mp}$ at $324-327^{\circ} \mathrm{C}$ (lit. $\mathrm{mp}$ $>300^{\circ} \mathrm{C}$ (Wang et al. 1989)) showed in the LSI mass spectra (positive ion and negative ion mode) quasimolecular ion peaks $[\mathrm{M}+\mathrm{H}]^{+}$at $\mathrm{m} / \mathrm{z} 301$ and $[\mathrm{M}-\mathrm{H}]^{-}$at $\mathrm{m} / \mathrm{z} 299$, consistent with a molecular formula $\mathrm{C}_{16} \mathrm{H}_{12} \mathrm{O}_{6}$, and further important peaks at $\mathrm{m} / z 286\left[\mathrm{M}-\mathrm{CH}_{3}\right]^{+}$and $284[\mathrm{M}-$ $\left.\mathrm{CH}_{3}\right]^{-}$. The UV spectra indicated a flavonol with free hydroxyl groups at C-5, C-7 and C-4' and lack of the orthodihydroxyl grouping in the B-ring, whereas proton in hydroxyl group at C-3 was substituted. The interpretation of spectroscopic data (UV, LSI MS, ${ }^{1} \mathrm{H}$ NMR) which were also comparable to the literature values (Bacon et al. 1978; Mabry et al. 1970) suggested kaempferol 3-methyl ether (isokaempferide).

UV $\lambda_{\max }{ }^{\mathrm{MeOH}} \mathrm{nm}: 268,342 ;(+\mathrm{NaOMe}): 263,405 ;(+$ $\left.\mathrm{AlCl}_{3}\right): 275,390 ;\left(+\mathrm{AlCl}_{3}+\mathrm{HCl}\right): 276,352,385$; (+ $\mathrm{NaOAc}): 269,347 ;\left(+\mathrm{NaOAc}+\mathrm{H}_{3} \mathrm{BO}_{3}\right): 267,342$;

${ }^{1} \mathrm{H}$ NMR (DMSO- $\left.d_{6}\right): \delta 3,87\left(3 \mathrm{H}, \mathrm{s}, 3-\mathrm{OCH}_{3}\right), 6,18(1 \mathrm{H}$, $d, J=1,8 \mathrm{~Hz}, \mathrm{H}-6), 6,50(1 \mathrm{H}, d, J=1,8 \mathrm{~Hz}, \mathrm{H}-8), 6,92$ $\left(2 \mathrm{H}, d, J=9,5 \mathrm{~Hz}, \mathrm{H}-3^{\prime}, \mathrm{H}-5\right.$ ') $, 7,56\left(2 \mathrm{H}, d, J=8,5 \mathrm{~Hz}, \mathrm{H}-2^{\prime}\right.$, H-6'), 12,97 (1H, s, 5-OH) (Table 1).

TABLE 1. Chromatographic (TLC) data for compounds 1-3 4).

\begin{tabular}{lccc}
\hline & \multicolumn{3}{c}{$\mathrm{R}_{\mathrm{f}}$} \\
\cline { 2 - 4 } Mobile phases 1,2,3) & 1 & 2 & 3 \\
\hline $50 \% \mathrm{AcOH}^{2)}$ & 0.27 & 0.50 & 0.51 \\
$\mathrm{AHW}^{2)}$ & 0.46 & 0.68 & 0.69 \\
$\mathrm{TBA}^{2)}$ & 0.66 & 0.86 & 0.83 \\
$\mathrm{EMW}^{3)}$ & 0.52 & 0.63 & 0.73 \\
$\mathrm{BM}^{3)}$ & 0.31 & 0.49 & 0.59 \\
\hline
\end{tabular}

1) TBA (t-buthanol - acetic acid - water $3: 1: 1 \mathrm{v} / \mathrm{v} / \mathrm{v})$; AHW (the Forestal solvent, acetic acid - hydrochloric acid - water 30:3:10 v/v/v); $50 \%$ $\mathrm{AcOH}=50 \%$ aqueous solution of acetic acid; EMW (ethyl acetate - methanol - water 20:3:2 v/v/v); BM (benzene - methanol 5:3 v/v)

2) on cellulose plates

3) on polyamide plates

4) 1 - luteolin; 2 - apigenin; 3 - kaempferol 3-methyl ether

LSI positive ion mass spectrum of compound 4 showed quasimolecular ion peak $[\mathrm{M}+\mathrm{H}]^{+}$at $\mathrm{m} / \mathrm{z} 597$ consistent with a molecular formula $\mathrm{C}_{26} \mathrm{H}_{28} \mathrm{O}_{16}$ whereas negative ion spectrum showed another important ion [aglycone $-\mathrm{H}]^{-}$at $\mathrm{m} / \mathrm{z}$ 301. Acid hydrolysis revealed glucose and xylose determined by means of TLC with authentic standards and aglycone which was co-chromatographed with the one released after hydrolysis of compound 5 and identified as isoetin, showing the same $R_{f}$ values and fluorescence. The UV spectra data indicated a flavone with free hydroxyl group at C-5 and batochromic effect caused by addition of $\mathrm{NaOMe}$ was probably due to another free $\mathrm{OH}$ group at $\mathrm{C}-2$ '. Diagnostic shifts suggested sugar attachment in the B-ring at the 4'- or 2'- and 4'- or 4'- and 5'-positions. The ${ }^{1} \mathrm{H}$ NMR spectrum showed doublets at $\delta 6.17(\mathrm{H}-6)$ and $6.42(\mathrm{H}-8)$, singlets at $\delta 7.04(\mathrm{H}-3), 6.72(\mathrm{H}-3$ ') and 7.32 (H-6'). The singlet at $\delta 12.97$ was assigned to proton from 5-OH whereas singlet at $\delta 8.55$ and the broad singlet signal at $\delta 10.40$ probably correspond to protons of the 7-, 2'- (or $\left.5^{\prime}-\right)$ hydroxyls. In addition, the $\mathrm{H}-3$ ' signal ( $\left.\delta 6.72\right)$ was shifted downfield compared with that in the aglycone spectrum ( $\delta 6.50$ (Gluchoff-Fiasson et al. 1991)) suggesting this proton to be located at the ortho position of the glycosylated hydroxyl group. This spectrum revealed also the presence of two anomeric protons at $\delta 5.49(d, J=5.2 \mathrm{~Hz})$ and $4.96(d, J=6.9 \mathrm{~Hz})$ ascribed for the glucosyl and/or xylosyl moieties. The combined UV and NMR spectral data suggested the attachment of sugar moieties at 2'- and 4'- 
-position of the aglycone isoetin. Unfortunately, too small amount of this glycoside $(6 \mathrm{mg})$ made further structural investigation $\left({ }^{13} \mathrm{C}\right.$ NMR, HMBC, HMQC) impossible and therefore the precise positions of attachment of particular sugar moieties were not fully established.

UV $\lambda_{\max } \mathrm{MeOH}_{\mathrm{nm}}: 259,367 ;(+\mathrm{NaOMe}): 267,336,445$; $\left(+\mathrm{AlCl}_{3}\right): 271,324,405 ;\left(+\mathrm{AlCl}_{3}+\mathrm{HCl}\right): 266,387 ;(+$ $\mathrm{NaOAc}): 260,368 ;\left(+\mathrm{NaOAc}+\mathrm{H}_{3} \mathrm{BO}_{3}\right): 265,287,367$;

${ }^{1} \mathrm{H}$ NMR (DMSO- $\left.d_{6}\right)$ : $\delta$ 3,20-4,15 (m, H-2"'-H-5", H-2"'-H-6"'), 4,96 (1H, d, J = 6,9 Hz, H-1"), 5,49 (1H, d, $J=5,2 \mathrm{~Hz}, \mathrm{H}-1$ "' ), 6,17 (1H, $d, J=1,3 \mathrm{~Hz}, \mathrm{H}-6), 6,42(1 \mathrm{H}$, $d, J=1,3 \mathrm{~Hz}, \mathrm{H}-8), 6,72(1 \mathrm{H}, s, \mathrm{H}-3$ '), 7,04 (1H, $s, \mathrm{H}-3)$, 7,32 (1H, s, H-6'), 8,55 (1H, br s, 2'- or 5'-OH), 10,40 $(1 \mathrm{H}, b r s, 7-\mathrm{OH}), 12,97(1 \mathrm{H}, s, 5-\mathrm{OH})$.

Compound 5 showed the UV spectra and diagnostic shifts characteristic for a flavone with ortho-dihydroxyl groups in the B-ring (batochromic shift of band I with $\mathrm{NaOAc}$ $+\mathrm{H}_{3} \mathrm{BO}_{3}$ and with $\mathrm{AlCl}_{3}$ ) and free hydroxyl groups at $\mathrm{C}-5$ and $\mathrm{C}-4$ '. However, the presence of hypsochromic shift in the $\mathrm{NaOAc}$ spectrum in band II and also the lack of hypsochromic effect in the $\mathrm{MeOH}$ spectrum in relation to the aglycone spectra resulted from the substitution of the 7-hydroxyl group. The UV spectra of compound 5 are in agreement with literature data (Harborne 1978, 1991; Mabry et al. 1970). Acid hydrolysis yielded glucose and aglyconeisoetin, determined by comparing the obtained UV and ${ }^{1} \mathrm{H}$ NMR data with literature (Gluchoff-Fiasson et al. 1991; Harborne 1999; Marco et al. 1988). Furthermore, the ${ }^{1} \mathrm{H}$ NMR spectrum showed doublets at $\delta 6.40(\mathrm{H}-6)$ and 6.71 (H-8), singlets at $\delta 7.08$ (H-3), 6.82 (H-3'), 7.29 (H-6') and $13,10(5-\mathrm{OH})$. The presence of $\beta$-glucosyl moiety appeared at $\delta 5.07(d, J=7.4 \mathrm{~Hz}, \mathrm{H}-1$ ") $)$. In addition, the H-6 and $\mathrm{H}-8$ signals were apparently shifted downfield compared with those in the aglycone spectrum (Gluchoff-Fiasson et al. 1991; Harborne 1999; Marco et al. 1988) suggesting these protons are located at the ortho positions of the glycosylated hydroxyl group. All the NMR data are given in Table 2. Compound 5 was identified as isoetin 7-O- $\beta$-glucopyranoside.

UV $\lambda_{\text {max }} \mathrm{MeOH}_{\mathrm{nm}}$ :263, 373; (+ NaOMe): 200, 231, 414; $\left(+\mathrm{AlCl}_{3}\right): 266,339,436 ;\left(+\mathrm{AlCl}_{3}+\mathrm{HCl}\right): 272,323,409$; (+ NaOAc): 258, 373; (+ NaOAc $\left.+\mathrm{H}_{3} \mathrm{BO}_{3}\right): 403$.

The acid hydrolysis of compound 6 yielded isoetin and glucuronic acid which were determined by TLC analyses with authentic samples (isoetin liberated after hydrolysis of compound 5). The UV spectral data were typical for flavone with free $\mathrm{OH}$ groups at C-5, C-7, C-2' and the absence of ortho-dihydroxyl grouping in the B-ring. This glycoside showed in the LSI negative ion mass spectrum a quasimolecular ion peak $[\mathrm{M}-\mathrm{H}]^{-}$at $\mathrm{m} / \mathrm{z} 477$, consistent with a molecular formula $\mathrm{C}_{21} \mathrm{H}_{18} \mathrm{O}_{13}$, and further important peaks at $\mathrm{m} / \mathrm{z} 303$ [aglycone $+\mathrm{H}]^{+}$and 301 [aglycone $\left.-\mathrm{H}\right]^{-}$. The $\mathrm{UV}$, LSI MS and ${ }^{1} \mathrm{H}$ NMR data are in agreement with those reported for the known isoetin 4'-O- $\beta$-glucuronide in literature (Pauli and Junior 1995).

UV $\lambda_{\text {max }} \mathrm{MeOH}_{\mathrm{nm}}$ : 258, 287, 371; (+ NaOMe): 267, 337; $\left(+\mathrm{AlCl}_{3}\right): 271,293,325,404 ;\left(+\mathrm{AlCl}_{3}+\mathrm{HCl}\right): 266,386$; (+ NaOAc): 260, 287, 369; (+ $\left.\mathrm{NaOAc}+\mathrm{H}_{3} \mathrm{BO}_{3}\right): 267,287$, 373 ;

${ }^{1} \mathrm{H}$ NMR (DMSO- $\left.d_{6}\right): \delta 3,29-3,44$ (3H, m, H-2"-H-4"), $3,56(1 \mathrm{H}, d, J=7 \mathrm{~Hz}, \mathrm{H}-5$ "), 4,75 (1H, br $s, \mathrm{H}-1$ "), 6,16 (1H, $s, \mathrm{H}-6), 6,43$ (1H, $s, \mathrm{H}-8), 6,86\left(1 \mathrm{H}, s, \mathrm{H}-3^{\prime}\right), 7,07$ $(1 \mathrm{H}, s, \mathrm{H}-3), 7,31$ (1H, $s, \mathrm{H}-6$ '), 13,01 (1H, $s, 5-\mathrm{OH})$.
TABLE 2. ${ }^{1} \mathrm{H}$ and ${ }^{13} \mathrm{C}$ NMR data for compound $5^{1,2,3)}$ in DMSO- $d_{6}$.

\begin{tabular}{|c|c|c|}
\hline \multirow{2}{*}{ Position } & \multicolumn{2}{|c|}{5} \\
\hline & $\delta \mathrm{C}$ & $\delta \mathrm{H}$ \\
\hline 2 & 162.0 & \\
\hline 3 & 106.8 & $7.08(1 \mathrm{H}, \mathrm{s})$ \\
\hline 4 & 182.0 & \\
\hline 5 & 161.0 & $13.10(1 \mathrm{H}, \mathrm{s})$ \\
\hline 6 & 99.8 & $6.40(1 \mathrm{H}, \mathrm{d}, 1.9)$ \\
\hline 7 & 162.7 & \\
\hline 8 & 94.4 & $6.71(1 \mathrm{H}, \mathrm{d}, 1.9)$ \\
\hline 9 & 157.0 & \\
\hline 10 & 104.0 & \\
\hline 1 ' & 110.0 & \\
\hline 2 ' & 150.0 & \\
\hline $3^{\prime}$ & 105.0 & $6.82(1 \mathrm{H}, \mathrm{s})$ \\
\hline $4^{\prime}$ & 149.0 & \\
\hline 5, & 139.0 & \\
\hline 6 & 114.0 & $7.29(1 \mathrm{H}, \mathrm{s})$ \\
\hline $1 "$ & 101.0 & $5.07(1 \mathrm{H}, \mathrm{d}, 7.4)$ \\
\hline $2 ”$ & 73.1 & \\
\hline $3 "$ & 76.3 & $3.20-3.50(1 \mathrm{H}, \mathrm{m})$ \\
\hline $4 "$ & 69.4 & \\
\hline $5 "$ & 77.1 & \\
\hline $6 "$ & 60.5 & $3.70(1 \mathrm{H}$, br d, 10.1$)$ \\
\hline
\end{tabular}

1) $\delta$ values in ppm, $J$ values in $\mathrm{Hz}$ (in parentheses)

2) Assignments were established by COSY, HMQC and HMBC experiments; literature values for some known glysosides of isoetin were also helpful because of the obvious lack of data for the examined compound (Gluchoff-Fiasson et al. 1991; Marco et al. 1988; Pauli and Junior 1995; Shi et al. 2008).

3) 5 - Isoetin 7-O- $\beta$-glucopyranoside

Compound 7 appeared as light yellow needles with melting point at $261-263^{\circ} \mathrm{C}$ (lit. mp $261-263^{\circ} \mathrm{C}$ (Królikowska and Wolbis 1981)). Acid hydrolysis yielded glucose and luteolin identified by TLC with authentic standards. UV data with characteristic batochromic shifts clearly pointed to the free hydroxyl groups at C-5, C-4' and also ortho-dihydroxyl groups in the B-ring of a flavone nucleus, whereas $\mathrm{OH}$ group at $\mathrm{C}-7$ was evidently substituted (the lack of batochromic shift of band II with $\mathrm{NaOAc}$ and the presence of hypsochromic effect in the NaOAc spectrum in band II in relation to aglycone). Furthermore, the ${ }^{1} \mathrm{H}$ NMR spectrum showed that the H-6 $(\delta 6.43)$ and H-8 $(\delta 6.78)$ signals were apparently shifted downfield compared with those in the aglycone spectrum suggesting these protons located at the ortho positions of the glycosylated hydroxyl group. The presence of $\beta$-glucosyl moiety appeared at $\delta 5.07(d, J=$ $7.4 \mathrm{~Hz}, \mathrm{H}-1$ "). All the obtained values of the UV and ${ }^{1} \mathrm{H}$ NMR spectra were in a perfect agreement with literature data for luteolin 7-O- $\beta$-D-glucopyranoside (Harborne 1999; Klimek and Królikowska 1984; Królikowska and Wolbiś 1981; Mabry et al. 1970; Williams et al. 1996). The identification was supported by the results of $1 \mathrm{D}$ and $2 \mathrm{D}$ -TLC with authentic standard.

UV $\lambda_{\text {max }} \mathrm{MeOH} \mathrm{nm}: 256,348 ;$ (+ NaOMe): 263, 403; (+ $\left.\mathrm{AlCl}_{3}\right): 273,419$; (+ $\left.\mathrm{AlCl}_{3}+\mathrm{HCl}\right): 276,357,389$; (+ $\mathrm{NaOAc}): 256,350 ;\left(+\mathrm{NaOAc}+\mathrm{H}_{3} \mathrm{BO}_{3}\right): 255,378$;

${ }^{1} \mathrm{H}$ NMR (DMSO- $\left.d_{6}\right): \delta 3,2-3,5$ (1H, $m, \mathrm{H}-3$ ") $, 3,70(1 \mathrm{H}$, br $d, J=10,5 \mathrm{~Hz}, \mathrm{H}-6 "), 5,07$ (1H, $d, J=7,4 \mathrm{~Hz}, \mathrm{H}-1 ")$, $6,43(1 \mathrm{H}, d, J=2,0 \mathrm{~Hz}, \mathrm{H}-6), 6,78(1 \mathrm{H}, d, J=2,0 \mathrm{~Hz}, \mathrm{H}-8)$, $6,75(1 \mathrm{H}, s, \mathrm{H}-3), 6,89(1 \mathrm{H}, d, J=8,3 \mathrm{~Hz}, \mathrm{H}-5$ '), 7,41 (1H, $d, J=2,1 \mathrm{~Hz}, \mathrm{H}-2$ ') $, 7,44(1 \mathrm{H}, d d, J=2,0 ; 8,3 \mathrm{~Hz}, \mathrm{H}-6$ '), $12,98(1 \mathrm{H}$, br s, 5-OH). 
Compound 8 - light pink needles with melting point at 202-205 ${ }^{\circ}$ (lit. mp $190-195^{\circ} \mathrm{C}$ (Yoshizaki et al. 1987)) had a molecular formula estimated from its LSI MS as $\mathrm{C}_{21} \mathrm{H}_{20} \mathrm{O}_{11}$ (quasimolecular ion peaks $[\mathrm{M}+\mathrm{H}]^{+}$at $\mathrm{m} / z 449$ and $[\mathrm{M}-\mathrm{H}]^{-}$at $\left.\mathrm{m} / \mathrm{z} 447\right)$. Mass spectra showed also other important ions at $\mathrm{m} / \mathrm{z} 287$ [aglycone $+\mathrm{H}]^{+}$and 285 [aglycone $-\mathrm{H}]^{-}$. Acid hydrolysis gave glucose and luteolin identified by TLC with authentic standards. The UV spectral data suggested a flavone which was glycosylated in the B-ring because of hypsochromic shifts to shorter wavelengths in relation to aglycone spectra (spectrum in methanol and spectrum after adding of $\mathrm{NaOAc}$ ). In addition, the lack of diagnostic shifts in the $\mathrm{NaOAc} / \mathrm{H}_{3} \mathrm{BO}_{3}$ spectrum and in the $\mathrm{AlCl}_{3} / \mathrm{HCl}$ spectrum (in relation to that with $\mathrm{AlCl}_{3}$ ) showed the absence of ortho-dihydroxyl groups in the B-ring. However, the hydroxyl groups at C-5 and C-7 apparently were not substituted. Furthermore, in the ${ }^{1} \mathrm{H}$ NMR spectrum only the H-5' signal was shifted downfield compared with the one in the aglycone spectrum suggesting this proton was located at the ortho position to the glycosylated hydroxyl group what confirmed sugar attachment in the B-ring at the 4'- position. This spectrum revealed also the presence of an anomeric proton at $\delta 4.88(d, J=7.2 \mathrm{~Hz}$, H-1") of the $\beta$-glucosyl moiety. These observations were further supported by HMBC correlation between $\delta 4.88$ (H-1") and $\delta 148,5$ (C-4') (Table 3) which pointed out the presence of a glucose moiety at C-4'. The interpretation of spectroscopic data (UV, LSI MS, NMR) which were also comparable to literature values (Harborne 1999; Kellam et al. 1993; Mabry et al. 1970; Markham and Porter 1974; Yoshizaki et al. 1987) proved compound 8 was luteolin 4'-O- $\beta$-glucopyranoside. Full NMR data are given in Table 3.

UV $\lambda_{\max } \mathrm{MeOH}_{\mathrm{nm}}: 244,269,335$; (+ NaOMe): 267, 377; $\left(+\mathrm{AlCl}_{3}\right): 277,351,384 ;\left(+\mathrm{AlCl}_{3}+\mathrm{HCl}\right): 279,340,384$; (+ NaOAc): 270, 336; (+ NaOAc $\left.+\mathrm{H}_{3} \mathrm{BO}_{3}\right): 269,334$.

TABLE 3. NMR data for compound $8^{1,2,3)}$ in DMSO- $d_{6}$.

\begin{tabular}{|c|c|c|c|}
\hline $\begin{array}{l}\text { Posi- } \\
\text { tion }\end{array}$ & $\delta \mathrm{H}$ & $\delta \mathrm{C}$ & $\begin{array}{c}{ }^{1} \mathrm{H}^{-13} \mathrm{C} \text { correlations } \\
\text { (HMBC) }\end{array}$ \\
\hline 2 & & 163.1 & H-3, H-2', Н-6' \\
\hline 3 & $6.82(1 \mathrm{H}, \mathrm{s})$ & 103.9 & \\
\hline 4 & & 181.8 & $\mathrm{H}-3$ \\
\hline 5 & $12.90(1 \mathrm{H}, \mathrm{s})$ & 161.4 & $\mathrm{H}-5 \mathrm{OH}, \mathrm{H}-6$ \\
\hline 6 & $6.19(1 \mathrm{H}, \mathrm{d}, 1.9)$ & 98.9 & $\mathrm{H}-5 \mathrm{OH}, \mathrm{H}-8$ \\
\hline 7 & & 164.3 & H-6, H-8 \\
\hline 8 & $6.48(1 \mathrm{H}, \mathrm{d}, 1.9)$ & 94.0 & H-6 \\
\hline 9 & & 157.3 & $\mathrm{H}-8$ \\
\hline 10 & & 103.8 & H-3, H-6, H-8, H-5OH \\
\hline $1^{\prime}$ & & 124.7 & H-3, H-5 \\
\hline $2^{\prime}$ & $7.49(1 \mathrm{H}, \mathrm{d}, 2.1)$ & 113.6 & H-6 \\
\hline $3^{\prime}$ & & 146.9 & H-2', H-5' \\
\hline $4^{\prime}$ & & 148.5 & H-2', H-5', H-6', H-1', \\
\hline $5^{\prime}$ & $7.23(1 \mathrm{H}, \mathrm{d}, 8.6)$ & 115.9 & \\
\hline $6^{\prime}$ & $7.51(1 \mathrm{H}, \mathrm{dd}, 2.1,8.6)$ & 118.5 & H-2' \\
\hline $1 "$ & $4.88(1 \mathrm{H}, \mathrm{d}, 7.2)$ & 101.1 & H-2", H-3" \\
\hline $2 "$ & $3.30(2 \mathrm{H}, \mathrm{m})$ & 73.2 & H-3" \\
\hline $3 "$ & & 75.8 & H-2", H-5" \\
\hline $4 "$ & $3.18(1 \mathrm{H}, \mathrm{m})$ & 69.7 & \\
\hline $5 "$ & $3.37(1 \mathrm{H}$, br s $)$ & 77.3 & $\mathrm{H}-6 \mathrm{~b} "$ \\
\hline $6 "$ & $\begin{array}{l}6 a "-3.71(1 \mathrm{H}, \mathrm{dd}, 10.8,3.5) \\
6 \mathrm{~b} "-3.47(1 \mathrm{H}, \mathrm{dd}, 11.5,5.8)\end{array}$ & 60.7 & \\
\hline
\end{tabular}

1) $\delta$ values in ppm, $J$ values in $\mathrm{Hz}$ (in parentheses)

2) Assignments were established by COSY, HMQC and HMBC experiments which enabled revision of C-2 and C-7 signals reported in a reference (Kellam et al. 1993; Yoshizaki et al. 1987).

3) 8 - Luteolin 4'-O- $\beta$-glucopyranoside
Compound 9 was a beige powder with $\mathrm{mp}$ at $192-195^{\circ} \mathrm{C}$. Acid hydrolysis yielded glucose and apigenin identified by TLC with authentic standards. The UV spectral data were typical for a flavone with free $\mathrm{OH}$ groups at C-5, C-4' and absent ortho-dihydroxyl grouping in the B-ring. The lack of the batochromic shift of band II with $\mathrm{NaOAc}$ and the presence of the hypsochromic effect in the NaOAc spectrum (band II) in relation to aglycone resulted from the substitution of the 7-hydroxyl. This conclusion was supported by the fact the H-6 $(\delta 6.42)$ and $\mathrm{H}-8(\delta 6.81)$ signals in the ${ }^{1} \mathrm{H}$ NMR spectrum were apparently shifted downfield compared with those in the aglycone spectrum suggesting these protons to be located at the ortho positions of the glycosylated hydroxyl group. Furthermore, the ${ }^{1} \mathrm{H}$ NMR spectrum showed broad signal at $\delta 13.00(5-\mathrm{OH})$, doublets at $\delta 6.91$ (H-3', H-5'), 7.94 (H-2', H-6') and a singlet at $\delta 6.85(\mathrm{H}-3)$. The presence of $\beta$-glucosyl moiety appeared at $\delta 5.04(d, J=7.2 \mathrm{~Hz}, \mathrm{H}-1$ "). All the obtained UV and ${ }^{1} \mathrm{H}$ NMR data were in an agreement with literature data for apigenin 7-O- $\beta$-glucopyranoside (Harborne 1999; Klimek and Królikowska 1984; Mabry et al. 1970; Markham 1977). The identification was supported by the results of $1 \mathrm{D}$ and $2 \mathrm{D}$-TLC with authentic standard showing the same $\mathrm{R}_{\mathrm{f}}$ and fluorescence.

UV $\lambda_{\max }{ }^{\mathrm{MeOH}} \mathrm{nm}: 267,332 ;(+\mathrm{NaOMe}): 264,388 ;(+$ $\left.\mathrm{AlCl}_{3}\right): 275,298,347,380 ;\left(+\mathrm{AlCl}_{3}+\mathrm{HCl}\right): 275,298$, 347, 380; (+ NaOAc): 267, 332; (+ NaOAc $\left.+\mathrm{H}_{3} \mathrm{BO}_{3}\right): 266$, 332 ;

${ }^{1} \mathrm{H}$ NMR (DMSO- $\left.d_{6}\right): \delta 3,15-3,50$ (1H, $m, \mathrm{H}-3$ ”), 3,70 $(1 \mathrm{H}, d, J=8,5 \mathrm{~Hz}, \mathrm{H}-6 "), 5,04$ (1H, $d, J=7,2 \mathrm{~Hz}, \mathrm{H}-1$ "), 6,42 (1H, br s, H-6), 6,81 (1H, br s, H-8), 6,85 (1H, s, H-3), $6,91\left(2 \mathrm{H}, d, J=8,4 \mathrm{~Hz}, \mathrm{H}-3^{\prime}, \mathrm{H}-5^{\prime}\right), 7,94(2 \mathrm{H}, d, J=8,4$ Hz, H-2', H-6'), 13,00 (1H, br s, 5-OH) (Table 4).

Compound 10 with $\mathrm{mp}$ at $172-175^{\circ}$ released after acid hydrolysis esculetin and glucose identified by TLC with authentic standards. This glycoside revealed characteristic light pink fluorescence in ultraviolet light at $365 \mathrm{~nm}$ which turned into yellow-orange after chromatogram derivatization with $10 \% \mathrm{KOH}$ (Cazes 2001; Williams et al. 1996). LSI negative ion mass spectrum showed quasimolecular ion peak $[\mathrm{M}-\mathrm{H}]^{-}$at $\mathrm{m} / \mathrm{z} 339$ consistent with a molecular formula $\mathrm{C}_{15} \mathrm{H}_{16} \mathrm{O}_{9}$. In the ${ }^{1} \mathrm{H}$ NMR spectrum, doublets at $\delta 6.29(J=9.5 \mathrm{~Hz}, \mathrm{H}-3)$ and $7.85(J=9.5 \mathrm{~Hz}, \mathrm{H}-4)$ have been observed which are characteristic for benzo- $\alpha$-pyrone derivatives. This spectrum showed also two singlets at $\delta 7.21(\mathrm{H}-5)$ and $7.05(\mathrm{H}-8)$ and revealed the presence of an anomeric proton at $\delta 4.94$ ( $\left.b r s, H-1^{\prime}\right)$ of the $\beta$-glucosyl

TABLE 4. Chromatographic (TLC) data for compounds 4-9 3).

\begin{tabular}{lcccccc}
\hline & \multicolumn{7}{c}{$\mathrm{R}_{\mathrm{f}}$} \\
Mobile phases ${ }^{1,2)}$ & \multicolumn{7}{c}{ ( } & 5 & 6 & 7 & 8 & 9 \\
\cline { 2 - 7 } & 0.62 & 0.24 & 0.48 & 0.36 & 0.58 & 0.61 \\
\hline BAW & - & - & - & 0.20 & 0.40 & 0.34 \\
TBA & 0.05 & 0.05 & 0.08 & 0.15 & 0.11 & 0.22 \\
$15 \%$ AcOH & & &
\end{tabular}

1) BAW (n-buthanol - acetic acid - water $4: 1: 5 \mathrm{v} / \mathrm{v} / \mathrm{v})$; TBA (t-buthanol acetic acid - water $3: 1: 1 \mathrm{v} / \mathrm{v} / \mathrm{v}) ; 15 \% \mathrm{AcOH}=15 \%$ aqueous solution of acetic acid

2) on cellulose plates

3) 4 - isoetin xyloside-glucoside; 5 - isoetin 7-O- $\beta$-glucopyranoside; 6 isoetin 4'-O- $\beta$-glucuronide; 7 - luteolin 7-O- $\beta$-glucopyranoside; 8 - luteolin 4'-O- $\beta$-glucopyranoside; 9 - apigenin 7-O- $\beta$-glucopyranoside 
moiety. The obtained data and the ${ }^{1} \mathrm{H}$ NMR values, which were comparable to those in the literature (Kisiel and Michalska 2002), suggested esculetin 7-O- $\beta$-glucopyranoside (cichoriin).

${ }^{1} \mathrm{H}$ NMR $\left(\mathrm{CD}_{3} \mathrm{OD}\right): \delta 3,03(1 \mathrm{H}, d d, J=7,4 ; 7,3 \mathrm{~Hz}, \mathrm{H}-$ -4'), 3,30 (3H, m, H-2', H-3', H-5'), 3,53 (1H, $m$, H-6a'), 3,65 (1H, m, H-6b'), 4,94 (1H, br s, H-1'), 6,29 (1H, $d, J=$ 9,5 Hz, H-3), 7,05 (1H, s, H-8), 7,21 (1H, s, H-5), 7,85 $(1 \mathrm{H}, d, J=9,5 \mathrm{~Hz}, \mathrm{H}-4)$.

Acid hydrolysis of compound 11 gave umbelliferone and glucose identified by TLC with authentic standards. The ${ }^{1} \mathrm{H}$ NMR spectrum showed five signals of the protons of the benzo- $\alpha$-pyrone system - four doublets at $\delta 6.32(\mathrm{H}-3)$, 8.00 (H-4), 7.64 (H-5), 7.04 (H-8) and also doublet of doublets at $\delta 6.99$ (H-6), and the presence of anomeric proton of the $\beta$-glucosyl moiety at $\delta 5.02(d, J=7.3 \mathrm{~Hz}, \mathrm{H}-1$ '). This glycoside was identified as umbelliferone 7-O- $\beta$-glucopyranoside (skimmin) (Hirata et al. 2000; Malet et al. 1995).

${ }^{1} \mathrm{H}$ NMR (DMSO- $\left.d_{6}\right): \delta 3,14(1 \mathrm{H}, m, \mathrm{H}-4$ ') $, 3,24(1 \mathrm{H}, m$, H-2'), 3,28 (1H, $m, \mathrm{H}-3$ ') , 3,42 (2H, $m, \mathrm{H}-5$ ', H-6b'), 3,67 $(1 \mathrm{H}, d d, J=9,5 ; 4,9 \mathrm{~Hz}, \mathrm{H}-6 \mathrm{a}), 5,02(1 \mathrm{H}, d, J=7,3 \mathrm{~Hz}$, H-1'), 6,32 (1H, $d, J=9,5 \mathrm{~Hz}, \mathrm{H}-3), 6,99$ (1H, $d d, J=6,3$; 2,3 Hz, H-6), 7,04 (1H, $d, J=2,2 \mathrm{~Hz}, \mathrm{H}-8), 7,64$ (1H, $d$, $J=8,6 \mathrm{~Hz}, \mathrm{H}-5), 8,00(1 \mathrm{H}, d, J=9,5 \mathrm{~Hz}, \mathrm{H}-4)$ (Fig. 1).

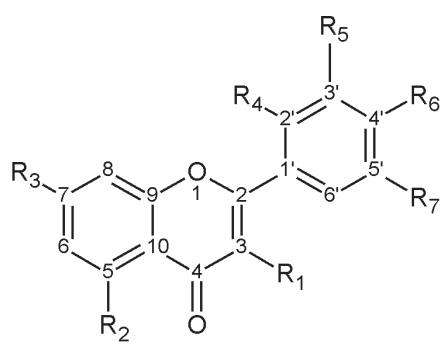

$\begin{array}{cccccccc} & \mathrm{R}_{1} & \mathrm{R}_{2} & \mathrm{R}_{3} & \mathrm{R}_{4} & \mathrm{R}_{5} & \mathrm{R}_{6} & \mathrm{R}_{7} \\ 1 & \mathrm{H} & \mathrm{OH} & \mathrm{OH} & \mathrm{H} & \mathrm{OH} & \mathrm{OH} & \mathrm{H} \\ 2 & \mathrm{H} & \mathrm{OH} & \mathrm{OH} & \mathrm{H} & \mathrm{H} & \mathrm{OH} & \mathrm{H} \\ 3 & \mathrm{OCH}_{3} & \mathrm{OH} & \mathrm{OH} & \mathrm{H} & \mathrm{H} & \mathrm{OH} & \mathrm{H} \\ 5 & \mathrm{H} & \mathrm{OH} & \mathrm{OGlc} & \mathrm{OH} & \mathrm{H} & \mathrm{OH} & \mathrm{OH} \\ 6 & \mathrm{H} & \mathrm{OH} & \mathrm{OH} & \mathrm{OH} & \mathrm{H} & \mathrm{OGlur} & \mathrm{OH} \\ 7 & \mathrm{H} & \mathrm{OH} & \mathrm{OGlc} & \mathrm{H} & \mathrm{OH} & \mathrm{OH} & \mathrm{H} \\ 8 & \mathrm{H} & \mathrm{OH} & \mathrm{OH} & \mathrm{H} & \mathrm{OH} & \mathrm{OGlc} & \mathrm{H} \\ 9 & \mathrm{H} & \mathrm{OH} & \mathrm{OGlc} & \mathrm{H} & \mathrm{H} & \mathrm{OH} & \mathrm{H}\end{array}$

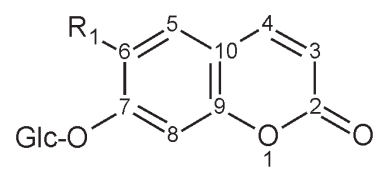

$$
\begin{array}{ll}
10 & \mathrm{R}_{1}=\mathrm{OH} \\
11 & \mathrm{R}_{1}=\mathrm{H}
\end{array}
$$

Glc $=\beta$-glucopyranosyl

Glur $=\beta$-glucuronosyl

Fig. 1. Structures of compounds 1-11.

Classical methods of liquid column and planar (paper, thin layer) chromatography proved to be sufficiently effective to isolate eleven polyphenolic compounds - two coumarin glycosides and nine flavonoids (three aglycones and six glycosides), from the aerial parts of Hieracium pilosella $\mathrm{L}$.
For the first time luteolin 4'-O- $\beta$-glucopyranoside, apigenin 7-O- $\beta$-glucopyranoside, kaempferol 3-methyl ether and esculetin 7-O- $\beta$-glucopyranoside were isolated from the examined plant species. The last two compounds have never been reported in this species until now and apigenin glycoside has been fully identified (sugar attachment). Furthermore, probably new isoetin diglycoside has been found and characterized as xyloside-glucoside where sugar moieties are probably placed at 4'- or 4'- and 2' (or 5') - positions. However, minute quantity of this compound has not allowed the full structure elucidation. To the best of our knowledge this is also the first NMR data report for isoetin $7-\mathrm{O}-\beta$-glucopyranoside. In addition, the new-isolated from $H$. pilosella L. cichoriin has never been discovered in the large genus Hieracium but only in other genera from the subfamily Cichorioidae e.g. Taraxacum sp. or Cichorium sp. (Kisiel and Michalska 2002; Williams et al. 1996). The wide range of flavonoids in mouse-ear hawkweed may explain diuretic, diastolic and antiphlogistic activities of the preparations from this plant.

\section{LITERATURE CITED}

AGELET A., VALLÈS J. 2003. Studies on pharmaceutical ethnobotany in the region of Pallars (Pyrenees, Catalonia, Iberian Penisula). Part II. New or very rare uses of previously known medicinal plants. J. Ethnopharmacol. 84: 211-227.

BACON J.D., URBATSCH L.E., BRAGG L.H., MABRY T.J., NEUMAN P., JACKSON D.W. 1978. The flavonoids of Tetragonotheca (Compositae). Phytochemistry 17: 1939-1943.

BATE-SMITH E.C., SELL P.D., WEST C. 1968. Chemistry and taxonomy of Hieracium L. and Pilosella Hill. Phytochemistry 7: $1165-1169$.

BEAUX D., FLEURENTIN J., MORTIER F. 1999. Effect of extracts of Ortosiphon stamineus Benth, Hieracium pilosella L., Sambucus nigra L. and Arctostaphylos uva-ursi (L.) spreng. In Rats. Phytother. Res. 13: 222-225.

BOLLE P., BELLO U., FACCENDINI P., MARTINOLI L., TITA B. 1993. Hieracium pilosella L.: pharmacological effect of ethanol extract. Pharmacol. Res. 27: 29.

BRODA B., MOWSZOWICZ J. 2000. Przewodnik do oznaczania roślin leczniczych, trujących i użytkowych. PZWL, Warszawa. (in Polish)

CAZES J. 2001. Encyclopedia of Chromatography. Marcel Dekker, Inc., New York-Basel.

GAWROŃSKA-GRZYWACZ M., KRZACZEK T. 2006a. Free and bound phenolic acids in inflorescences and rhizomes with roots of Hieracium pilosella L. (Asteraceae). Acta Soc. Bot. Pol. 75(3): 215-218.

GAWROŃSKA-GRZYWACZ M., KRZACZEK T. 2007. Identification and determination of triterpenoids in Hieracium pilosella L. J. Sep. Sci. 30: 746-750.

GAWROŃSKA-GRZYWACZ M., KRZACZEK T. 2006b. Sterol composition from inflorescences of Hieracium pilosella L. Acta Soc. Bot. Pol. 75(1): 29-32.

GLUCHOFF-FIASSON K., FAVRE-BONVIN J., FIASSON J.L. 1991. Glycosides and acylated glycosides of isoetin from European species of Hypochoeris. Phytochemistry 30 (5): 1673-1675 .

HAAG-BERRURIER M., DUQUÉNOIS P. 1962. Extraction et caractérisation physicochimique de la lutéoline dans les fleurs de la Piloselle, Hieracium pilosella L. C. R. Seances Acad. Sci. 254: 3419-3421.

HAAG-BERRURIER M., DUQUÉNOIS P. 1963. Sur la présence d'un 7- $\beta$-glucoside de la lutéoline dans les feuilles de la Piloselle, Hieracium pilosella C. R. Seances Acad. Sci. III. 257: 3239-3241. 
HAAG-BERRURIER M., DUQUÉNOIS P. 1969. Les flavonoides de l'Hieracium murorum ssp. grandidens var. minoriceps. Phytochemistry 8: 681-683.

HARBORNE J.B. 1991. Revised structures for three isoetin glycosides, yellow flower pigments in Heywoodiella oligocephala. Phytochemistry 30(5): 1677-1678.

HARBORNE J.B. 1999. The Flavonoids: Advances in research since 1986. Chapman \& Hall, London.

HARBORNE J.B. 1978. The rare flavone isoetin as a yellow flower pigment in Heywoodiella oligocephala and in other Cichorieae. Phytochemistry 17: 915-917.

HENN H., PETIT D., VERNET P. 1988. Interference between Hieracium pilosella and Arrhenatherum elatius in colliery spoils of north of France. Oecologia 76: 268-272.

HIRATA T., SHIMODA K., FUJINO T., OHTA S. 2000. Biotransformation of hydroxycoumarins by the cultured cells of Nicotiana tabacum. J. Mol. Catal., B Enzym. 10: 477-481.

KELLAM S.J., MITCHELL K.A., BLUNT J.W., MUNRO M.H.G., WALKER J.R.L. 1993. Luteolin and 6-hydroxyluteolin glycosides from Hebe stricta. Phytochemistry 33(4): 867-869.

KISIEL W., MICHALSKA K. 2002. A new coumarin glucoside ester from Cichorium intybus. Fitoterapia 73: 544-546.

KLIMEK B., KRÓLIKOWSKA M. 1984. Związki flawonoidowe w kwiatach dziewanny wielokwiatowej - Verbascum thapsiforme Schrad. i dziewanny kutnerowatej - V. phlomoides L. (Scrophulariaceae). Acta Polon. Pharm. 41(2): 259-264. (in Polish with English summary)

KRÓLIKOWSKA M., WOLBIŚ M. 1981. Związki polifenolowe Inula britannica L. (Compositae). Acta Polon. Pharm. 38(1): 107-114. (in Polish with English summary)

KRZACZEK T., ŁUKASIEWICZ E., GAWROŃSKA-GRZYWACZ M. 2002. Sterols in the roots and herb from Hieracium pilosella L. Herba Pol. 48(4): 206-209.

MABRY T.J., MARKHAM K.R., THOMAS M.B. 1970. The Systematic Identification of Flavonoids. Springer-Verlag, BerlinHeidelberg-New York.

MALET C., VIDALOT J.L., OCHOA A., GALLEGO B., BROSA C., PLANAS A. 1995. Synthesis of 4-methylumbelliferylbeta-D-glucan oligosaccharides as specific chromophoric substrates of $(1 \rightarrow 3),(1 \rightarrow 4)$-beta-D-glucanohydrolases. Carbohydr. Res. 274: 285-301.

MARCO J.A., BARBERA O., RODRIGUEZ S., DOMINGO C., ADELL J. 1988. Flavonoids and other phenolics from Artemisia hispanica. Phytochemistry 27(10): 3155-3159.
MARKHAM K.R. 1977. Flavonoids and phylogeny of the "primitive" New Zealand hepatic, Haplomitrium gibbsiae. Phytochemistry 16: 617-619.

MARKHAM K.R., PORTER L.J. 1974. Luteolin 3',4'-di-O- $\beta$-D-glucuronide and luteolin 3'-O- $\beta$-D-glucuronide from Lunularia cruciata. Phytochemistry 13: 1553-1555.

PAULI G.F., JUNIOR P. 1995. Phenolic glycosides from Adonis aleppica. Phytochemistry 38(5): 1245-1250.

RAHMAN M.A.A., MOON S.S. 2007. Isoetin 5'-methyl ether, a cytotoxic flavone from Trichosanthes kirilowii. Bull. Kor. Chem. Soc. 28: 1261-1264.

SHELUYTO V.L., GLYZIN V.I., KRUGLOVA E.P., SMIRNOVA L.P. 1977. Flavonoidy iz Hieracium pilosella. Khim. Prir. Soedin. 860-862.

SHI S., ZHANG Y., ZHAO Y., HUANG K. 2008. Preparative isolation and purification of three flavonoid glycosides from Taraxacum mongolicum by high-speed counter-current chromatography. J. Sep. Sci. 31: 683-688.

WANG Y., HAMBURGER M., GUEHO J., HOSTETTMANN K. 1989. Antimicrobial flavonoids from Psiadia trinervia and their methylated and acetylated derivatives. Phytochemistry 28(9): 2323-2327.

WILLIAMS C.A., GOLDSTONE F., GREENHAM J. 1996. Flavonoids, cinnamic acids and coumarins from the different tissues and medicinal preparations of Taraxacum officinale. Phytochemistry 42(1): 121-127.

WRIGHT C.I., VAN-BUREN C.I., KRONER C.I., KONING M.M.G. 2007. Herbal medicines as diuretics: A review of the scientific evidence. J. Ethnopharmacol. 114: 1-31.

YOSHIZAKI M., FUJINO H., MASUYAMA M., ARISAWA M., MORITA N. 1987. A chemotaxonomic study of flavonoids in the leaves of six Trichosanthes species. Phytochemistry 26(9): 2557-2558.

ZIDORN C., GOTTSCHLICH G., STUPPNER H. 2002. Chemosystematic investigations on phenolics from flowerheads of Central European taxa of Hieracium sensu lato (Asteraceae). Plant Syst. Evol. 231: 39-58.

ZIDORN C., SCHUBERT B., STUPPNER H. 2005. Altitudinal differences in the contents of phenolics in flowering heads of three members of the tribe Lactucaceae (Asteraceae) occurring as introduced species in New Zealand. Biochem. Syst. Ecol. 33: $855-872$. 